\title{
SISTEM PENDUKUNG KEPUTUSAN PEREKRUTAN OPERATOR MESIN COMPUTER NUMERICAL CONTROL DENGAN METODE WEIGHTED PRODUCT
}

\section{Decision Support System To Hiring Numerical Control Computer Machine Operator Using Weighted Product Method}

\author{
Achmad Udin Zailani, dosen00270@unpam.ac.id ${ }^{1)}$, Ari Irawan,ari_irawan@tau.ac.id ${ }^{2)}$ \\ 1) Program Studi Teknik Informatika, Universitas Pamulang \\ 2) Program Studi Sistem Informasi, Tanri Abeng University
}

\begin{abstract}
The CNC (Computer Numerical Control) machine is an automated system operated by abstartprogrammed commands on a computer. CNC machines must be operated by a competent operator. The purpose of this research is to make a decision support system of recruitment of CNC machine operator. The method used is weighted product method. The weighted product method uses multiplication to attribute the attribute rating, where each attribute must be raised first with the attribute weights. This research has successfully applied the weighted product method in PT.Jatibaru Mandiri for recruitment of CNC machine operators so that recruitment is more objective and makes the recruitment system of CNC machine operator become more accurate..
\end{abstract}

Keywords: Recruitment Operators, CNC Machines, Weighted Product Methods

\begin{abstract}
ABSTRAK
Mesin CNC (Computer Numerical Control) merupakan sistem otomatisasi yang dioperasikan oleh perintah yang diprogram secara abstark pada komputer. Mesin CNC harus dioperasikan oleh operator yang berkompeten. Tujuan penelitian ini adalah membuat sistem pendukung pengambilan keputusan perekrutan operator mesin CNC. Metode yang digunakan adalah metode weighted product. Metode weighted product menggunakan perkalian untuk menghubungkan rating atribut, dimana setiap atribut harus dipangkatkan dahulu dengan bobot atribut yang bersangkutan.Penelitian ini berhasil menerapkan metode weighted product di PT.Jatibaru Mandiri untuk perekrutan operator mesin CNC sehingga perekrutan lebih objektif dan membuat sistem perekrutan operator mesin CNC menjadi lebih akurat.
\end{abstract}

Kata Kunci: Perekrutan Operator, Mesin CNC, Metode Weighted Product.

\section{PENDAHULUAN}

Pelayanan yang baik dan tepat waktu dalam pembuatannya merupakan faktor yang sangat penting dalam dunia bisnis yang bergerak dibidang perdagangan dan manufacturing. Pada era globalisasi ini, perkembangan teknologi sangatlah pesat, temasuk dibidang teknologi permesinan. Semua yang dibutuhkan harus dijalankan secara cepat. Mesin CNC (Computer Numerical Control) menjadi sebuah sistem otomatisasi mesin perkakas yang dioperasikan oleh perintah yang diprogram secara abstark pada komputer. Operator mesin $\mathrm{CNC}$ adalah sesorang yang bertugas mengoperasikan mesin $\mathrm{CNC}$, untuk membuat program sesuai dengan kebutuhan yang akan dibuat pada mesin CNC tersebut. Perekrutan operator yang dilakukan PT. Jatibaru Mandiri masih mengunakan sistem manual yaitu dengan mencatat data hasil dari tes-tes yang dilakukan kemudian hasil tes tersebut akan dihitung kembali untuk mendapatkan operator mesin perhitungan perekrutanpun masih kurang akurat. Dalam proses seleksi keputusan yang diambil sering dipengaruhi faktor subjektifitas dari pengambil keputusan. Subjektifitas terjadi karena pengambil keputusan belum bisa mendefinisikan dengan baik dalam menilai kelayakan calon. 
Banyak penelitian yang telah dilakukan tekait sistem rekruitmen untuk mengambil keputusan. Sistem penunjang keputusan dipandang sebagi sistem berbasis komputer interaktif, yang membantu para pengambil keputusan untuk menggunakan data dan berbagai model untuk memecahkan masalah-masalah tidak terstruktur [1]. Sistem pengambilan keputusan dapat membantu menyelesaikan masalah semi-terstruktur dan tak terstruktur, meningkatkan efektivitas manajerial dan meningkatkan poduktivitas analisis. Kebanykan metode yang dipilih adalah metode simple additive weighting, metode weighted product dan metode Fuzzy logic. Penelitian yang dilakukan oleh [2] dan [3] menunjukkan bahwa metode WP dapat digunakan dalam memutuskan peminatan siswa di SMA. Bebagai metode digunakan untuk membantu membuat keputusan berdasarkan kiteria seleksi yang ditentukan suatu perusahaan. Kriteria seleksi yang dimaksud dalam penelitian ini adalah kriteria penilaian yang digunakan oleh organisasi dalam menentukan seleksi karyawan.

Metode Weighted Product digunakan telah digunakan untuk membuat suatu sistem pendukung keputusan rekruitmen pegawai baru di PT. Ploss Asia. Hasilnya sistem yang diciptakan berhasil membuat sustu sistem pendukung keputusan rekrutmen karyawan yang objektif [4] . Kriteria yang dipertimbangkan adalah tes wawancara dan tes kemampuan.

Penelitian ini menggunakan metode WP karena metode WP merupakan salah satu metode penyelesaian multi kriteria dimana dalam perekrutan karyawan banyak kriteria yang harus dipertimbangkan. Pentingnya rekruitmen operator mesin CNC yang berkompeten, melatarbelakangi penelitian untuk membuat sistem pendukung keputusan operator mesin $\mathrm{CNC}$ pada PT. Jatibaru mandiri menggunakan metode weighted product (WP) berbasis desktop. Sistem pengambilan membantu pihak tertentu dalam menangani pemasalahan dengan menggunakan data dan model [5]. Metode WP digunkan untuk membantu memberikan usulan terhadap suatu masalah [6]. Metode WP dipilih karena memiliki proses perbaikan bobot yang akan diberikan kesetiap kriteria kemudian dilakukan pemangkatan antara nilai kriteria dengan bobot [7]. Bobot yang diperbaiki akan berjumlah satu dimana bobot tersebut bisa dipakai untuk perhitungan, hasil yang didapat dari metode WP juga akan berjumlah satu, menandakan keakuratan dalam melakukan perhitungan. Perancangan aplikasi ini menggunakan bahasa pemrograman JAVA berbasis desktop, hal ini disebabkan karena perusahaan tersebut menggunakanya data yang privasi sehingga cocok menggunakan basis desktop. Metode WP menggunakan perkalian untuk menghubungkan rating artibut, dimana rating setiap atribut harus dipangkatkan dulu dengan bobot atribut yang bersangkutan [8]. Proses ini sama halnya dengan proses normalisasi.

\section{METODOLOGI PENELITIAN}

\section{Metode Weigted Product}

Pemilihan calon operator mesin CNC dengan menggunakan fuzzy MADM dengan metode weigted product memelukan kriteria-kriteria dan bobot untuk melakukan perhitungan sehingga nilai dari setiap calon operator dapat di ketahui. Kriteria yang dipehitungkan adalah pengalaman kerja (C1), pendidikan teakhir (C2), tes technical skill (C3), tes wawancara (C4), tes psikotes (C5) dan sikap (C6). Pendekatanpendekatan untuk menentukan nilai bobot pada kriteria adalah pendekatan subyektif, objektif dan integrasi antara subyektif dan obyektif. Bobot (W) yang ditetapkan dalam hal ini adalah pengalaman kerja (bobot 4), pendidikan teakhir (bobot 3), tes technical skill (bobot 5), tes wawancara (bobot 3), tes psikotes (bobot 3) dan sikap (bobot 2). Semua kriteria yang dinilai dikonversikan kedalam sistem fuzzy.

Metode weighted product
menggunakan perkalian untuk
menghubungkan rating atribut, dimana
rating setiap atribut harus dipangkatkan
dulu dengan bobot yang bersangktutan.
Dalam penentuan nilai kepentingan atau


bobot pada aplikasi sistem penunjang keputusan sebagai alat bantu, pencarian nilai bobot atribut diberi peringkat 1 sampai 5 berdasarkan jenis dan beberapa kriteria yang telah dipilih sebelumnya. Proses ini sama halnya dengan proses normalisasi. Langkah penyelesaian dengan metode WP adalah sebagai berikut:

a. Perbaikan bobot (W)

$$
w j=\frac{w j}{\sum w j}
$$

b. Perhitungan vektor

$$
S_{i}=\prod_{i=1}^{n} x_{i j} w
$$

c. Poses perangkingan

$$
v_{i} \frac{\prod_{j=1}^{\mathrm{H}} X_{\mathrm{ij}}{ }^{\mathrm{wj}}}{\prod_{j=1}^{\mathrm{M}}\left(X_{\mathrm{j}^{\mathrm{j}}}\right)^{\mathrm{wj}}}
$$

\section{Perancangan database dan aplikasi}

Perancangan database atau basis data merupakan tahap pemodelan atau konseptual ke model database yang akan dipakai. Perancangan database meliputi perancangan yaitu ERD, transformasi ERD ke LRS, LRS, spesifikasi database, normalisasi.

Selanjutnya dilakukan perancangan aplikasi yang terdiri dari use case diagram, class diagram, sequence diagram dan activity diagram. Sequence diagram terdiri dari diagram login, diagram input data admin, diagram input data calon operator, diagram input data bobot dan diagram hitung WP.

\section{Perancangan basis data}

Basis penciptaan data yang saling terhubung dilakukan dengan perancangan data. Data yang ada disajikan dalam bentuk tabel. Dalam hal ini dibuat suatu struktur tabel dari sistem keputusan perekrutan operator mesin CNC di PT. Jatibaru Mandiri lengkap dari struktur tabel login hingga struktur tabel keputusan. Selanjutnya dilakukan pendekatan dalam membangun desain logika basis data relational yang tidak secara langsung berkaitan dengan model data, tetapi dengan menerapkan aturan dan kriteria standar untuk menghasilkan struktur tabel yang normal.

Rancangan selanjutnya dibuat dalam bentuk rancangan user interface atau atarmuka pengguna. Perancangan antarmuka sistem pendukung keputusan perekrutan calon operator mesin ini terdiri dari rancangan halaman login, menu utama, file App, master data, Perhitungan, input data admin, input data calon operator, input nilai bobot, dan pehitungan WP.

\section{Perangkat}

Perangkat keras yang diperlukan untuk mengimplemetasikan perangkat lunak dari sistem pendukung keputusan perekrutan calon operator mesin CNC pada PT. Jatibaru Mandiri adalah processor intel premium dual core, RAM $2 \mathrm{~Gb}$, hardidk $200 \mathrm{~Gb}$, monitor 19 inch, VGA card 256 $\mathrm{Mb}$, optical driver DVD-Rom/RW. Sedangkan perangkat lunak yang digunakan adalah window 7, bahasa pemrogaman java, database server MySQL 5.5 dan code editor netbeans 7.3.

\section{Pengujian sistem pendukung keputusan} Selanjutnya sistem aplikasi pengambilan keputusan diuji untuk menemukan kesalahan-kesalahan atau kekurangan-kekurangan pada perangkat lunak yang diuji. Pengujian bermaksud untuk mengetahui perangkat lunak yang dibuat sudah memenuhi kriteria yang sesuai dengan tujuan perancangan perangkat lunak tersebut. Pengujian perangkat lunak sistem pendukung keputusan rekrutmen pegawai menggunakan pengujian black box dan pengujian beta. Pengujian black box berfokus pada persyaratan fungsional perangkat lunak. Pengujian black box dibagi kedalam dua bagian, yaitu skenario pengujian black box dan hasil pengujian black box.

\section{HASIL DAN PEMBAHASAN}

Pembagian presentase pembobotan untuk perekrutan operator CNC adalah $20 \%$ 
untuk $\mathrm{C} 1$ (pengalaman kerja), 15\% untuk C2 (Pendidikan Akhir), 25\% untuk C3(Tes Technical Skill), 15\% untuk C4 (Tes Psikotes), $15 \%$ untuk C5( Tes Wawancara), dan $10 \%$ C6 (Sikap/Attitude). Dari pembagian persentasi pembobotan maka pengambilan keputusan memberikan bobot untuk setiap kriteria adalah:

$\mathrm{W}=\left[\begin{array}{llllll}4 & 3 & 5 & 3 & 3 & 2\end{array}\right]$

Tabel 1. Hasil Perhitungan Vektor (S)

\begin{tabular}{|c|c|c|c|c|c|c|c|}
\hline $\begin{array}{c}\text { Altenatif } \\
\text { operator }\end{array}$ & C1 & C2 & C3 & C4 & C5 & C6 & Hasil Vektor \\
\hline A1 & 2.1867 & 1.8923 & 2.6591 & 1.8913 & 1.7982 & 1.5294 & 57.2010 \\
\hline A2 & 2.3389 & 1.7982 & 2.6591 & 1.6656 & 1.7982 & 1.5294 & 52.0985 \\
\hline A3 & 2.1867 & 1.7982 & 2.6591 & 1.8913 & 1.7982 & 1.4788 & 52.5860 \\
\hline A4 & 2.3389 & 1.8913 & 2.8925 & 1.7982 & 1.6656 & 1.4788 & 56.6714 \\
\hline A5 & 1.9744 & 1.7982 & 2.6591 & 1.8913 & 1.8913 & 1.5294 & 51.6476 \\
\hline
\end{tabular}

Bobot awal terlebih dahulu diperbaiki sehingga bobot total $\Sigma$ wi $=1$.

Dari perhitungan diperoleh $\mathrm{w}_{1}=0.2, \mathrm{w}_{2}=$ $0.15, \mathrm{w}_{3}=0.25, \mathrm{w}_{4}=0.15, \mathrm{w}_{5}=0.15, \mathrm{w}_{6}=$ 0.1 . Hasil pehitungan vektor (S) dapat dilihat pada Tabel. 1.

Hasil perhitungan dari proses perangkingan dapat dilihat pada Tabel 2 .

Hasil perancangan aplikasi diantaranya adalah sequence diagram input data bobot dapat dilihat pada Gambar 1.

Tabel 2. Hasil Proses Perangkingan (V)

\begin{tabular}{|c|c|c|c|}
\hline $\begin{array}{c}\text { Altenatif } \\
\text { operator }\end{array}$ & $\begin{array}{c}\text { Hasil } \\
\text { Vektor }\end{array}$ & $\begin{array}{c}\text { Hasil } \\
\text { Perangkinan }\end{array}$ & Status \\
\hline A1 & 57.2010 & 0.2123 & Lolos \\
\hline A2 & 52.0985 & 0.1902 & Tidak Lolos \\
\hline A3 & 52.5860 & 0.1952 & Tidak Lolos \\
\hline A4 & 56.6714 & 0.2104 & Tidak Lolos \\
\hline A5 & 51.6476 & 0.1917 & Tidak Lolos \\
\hline
\end{tabular}

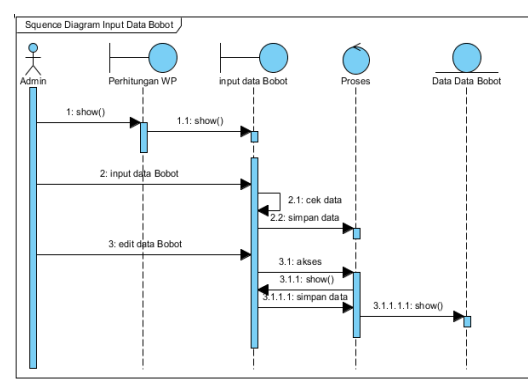

Gambar 1. Sequence Diagram Input Data Bobot

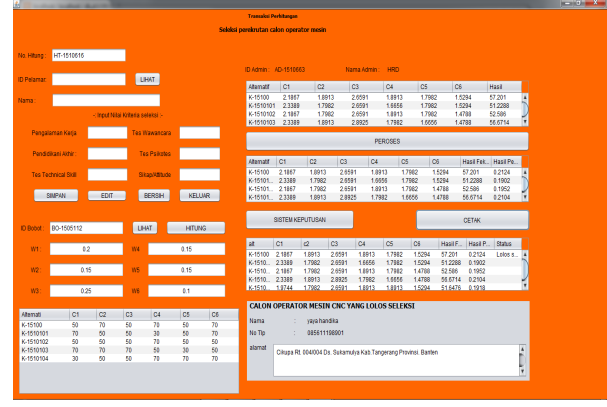

Gambar 2. Form Perhitungan

Tabel 3. Hasil Pengujian Pengelolaan Data Admin/staf HRD

\begin{tabular}{|c|c|c|c|}
\hline $\begin{array}{l}\text { Aktivitas } \\
\text { Yang } \\
\text { Dilakukan }\end{array}$ & $\begin{array}{c}\text { Yang } \\
\text { Diharapkan }\end{array}$ & Pengamatan & Kesimpulan \\
\hline \multicolumn{4}{|c|}{ Menambahkan Data Admin/staff HRD } \\
\hline $\begin{array}{l}\text { Pengguna } \\
\text { mengisi } \\
\text { seluruh isian } \\
\text { textfield }\end{array}$ & $\begin{array}{l}\text { Seluruh } \\
\text { textfield } \\
\text { terisi }\end{array}$ & $\begin{array}{l}\text { Seluruh } \\
\text { textfield } \\
\text { terisi }\end{array}$ & Diterima \\
\hline $\begin{array}{l}\text { Klik Tombol } \\
\text { Simpan }\end{array}$ & $\begin{array}{l}\text { Sistem dapat } \\
\text { menyimpan } \\
\text { kedalam } \\
\text { database }\end{array}$ & $\begin{array}{l}\text { Sistem dapat } \\
\text { menyimpan } \\
\text { kedalam } \\
\text { database }\end{array}$ & Diterima \\
\hline \multicolumn{4}{|c|}{ Mengubah Data Admin /staff HRD } \\
\hline $\begin{array}{l}\text { Pengguna } \\
\text { mengklik } \\
\text { tombol cari } \\
\text { lalu masukan } \\
\text { kode admin isi } \\
\text { semua textfield } \\
\text { yang akan } \\
\text { diubah }\end{array}$ & $\begin{array}{l}\text { Tombol cari } \\
\text { akan dapat } \\
\text { dimasukan } \\
\text { kode admin } \\
\text { tersebut dan } \\
\text { textfield bisa } \\
\text { terisi }\end{array}$ & $\begin{array}{l}\text { Tombol cari } \\
\text { akan dapat } \\
\text { dimasukan } \\
\text { kode admin } \\
\text { tersebut dan } \\
\text { textfield bisa } \\
\text { terisi }\end{array}$ & Diterima \\
\hline $\begin{array}{ll}\text { Klik } & \text { tombol } \\
\text { Edit } & \end{array}$ & $\begin{array}{lr}\text { Data yang } \\
\text { diubah akan } \\
\text { masuk ke } \\
\text { dalam } \\
\text { database dan } \\
\text { data } \\
\text { sebelumnya } \\
\text { berubah } \\
\end{array}$ & $\begin{array}{lr}\text { Data } & \text { yang } \\
\text { diubah } & \text { akan } \\
\text { masuk ke } & \text { kam } \\
\text { dalam } & \\
\text { database dan } \\
\text { data } \\
\text { sebelumnya } \\
\text { berubah } \\
\end{array}$ & Diterima \\
\hline \multicolumn{4}{|c|}{ Menghapus Data Admin/staff HRD } \\
\hline $\begin{array}{lr}\text { Klik tombol } \\
\text { cari } \\
\text { masukan lalu } \\
\text { admin id } \\
\text { staff ke dalam } \\
\text { textfield yang } \\
\text { akan dihapus. }\end{array}$ & $\begin{array}{l}\text { Tombol cari } \\
\text { dapat bisa } \\
\text { mengkosong } \\
\text { kan textfield } \\
\text { yang akan } \\
\text { diisi id admin } \\
\text { yang akan } \\
\text { dihapus } \\
\end{array}$ & $\begin{array}{l}\text { Tombol cari } \\
\text { dapat bisa } \\
\text { mengkosong } \\
\text { kan textfield } \\
\text { yang akan } \\
\text { diisi id admin } \\
\text { yang akan } \\
\text { dihapus } \\
\end{array}$ & Diterima \\
\hline $\begin{array}{ll}\text { Klik Tombol } \\
\text { Hapus }\end{array}$ & $\begin{array}{l}\text { Data } \\
\text { admin/staff } \\
\text { HRD pada } \\
\text { tabel hilang } \\
\text { atau terhapus }\end{array}$ & $\begin{array}{l}\text { Data } \\
\text { admin/staff } \\
\text { HRD pada } \\
\text { tabel hilang } \\
\text { atau terhapus }\end{array}$ & Diterima \\
\hline
\end{tabular}

Implementasi antarmuka dilakukan dengan setiap halaman program yang dibuat dan pengkodean dalam bentuk file program. Hasil implementasi antar muka terdiri dai form login, menu utama, input admin, input data calon operator, data calon operator, input bobot, data bobot, perhitungan dan laporan. Salah satu hasil implementasi 
yaiatu form perhitungan dapat dilihat pada Gambar 2.

Hasil pengujian black box sistem pendukung keputusan perekrutan calon operator mesin pada PT.Jatibaru Mandiri dilakukan pada setiap hasil implementasi antar muka. Salah satu hasil pengujian untuk seseoang mengisikan data benar dapat dilihat pada Tabel 3.

Keseluruhan hasil menunjukkan bahwa pengujian black box dengan kasus sampel uji yang telah dilakukan memberikan kesimpulan bahwa secara fungsional sistem sudah dapat menghasilkan output yang diharapkan.

\section{SIMPULAN}

\section{Simpulan}

Berdasarkan hasil pembahasan dapat disimpulkan bahwa penggunaan metode weighted product dalam perekrutan operator mesin CNC pada PT. Jatibaru mandiri memberikan perhitungan yang jelas dan objektif dibandingkan dengan sistem sebelumnya yang masih bersifat subjektif. Perhitungan dengan aplikasi perekrutan dengan metode weighted product lebih akurat dibandingkan dengan sistem yang digunakan sebelumnya. Dengan demikian, implementasi metode weighted product dapat digunakan untuk sistem pendukung keputusan perekrutan calon operator mesin CNC pada PT. Jatibaru Mandiri.

Saran

Sistem pendukung keputusan perekrutan calon operator mesin $\mathrm{CNC}$ dengan metor weighted product perlu dilakukan proses update basis pengetahuan secara berkala untuk menjaga keakuratannya. Penelitian dapat dikembangkan dengan membuat sistem pengambilan keputusan dengan metode lainnya, sehingga dapat dibandingkan dengan metode weighted product yang sudah digunakan.

\section{DAFTAR PUSTAKA}

[1] Turban, E., Aronson, J.E., and Liang T.P., 2005, Decision Support Systems and Intelligent Systems (Sistem Pendukung Keputusan dan Sistem Kecerdasan, Penerbit Andi, Yogyakarta.

[2] Nurul, F, 2014. Istem Pendukung Keputusan Peminatan Sma Menggunakan Metode Weighted Product, Jurnal Kependidikan, Vol 44 (2), hal 139-145.

[3] Gigih, A, P., Sistem Pendukung Keputusan Penentuan Peminatan Peserta Didik Menggunakan Metode Weighted Product Berbasis Web, Jurnal Masyarakat Infomatikai, Vol (6 (11), hal 27-35.

[4] Diah, A. K., 2012, Sistem pendukung keputusan rekrutmen karyawan produksi menggunakan metode weighted product pada PT.Ploss Asia Semarang, Skripsi, Program Studi Sistem Informasi, Universitas Dian Nuswantoro Semarang, Semarang.

[5] Nency, Nurjanah., dkk., 2015. Sistem Pendukung Keputusan Pembelian Sepeda Motor dengan Metode Weighted Poduct, Jurnal Infomatika Mulawarman, Vol 10 (2), hal 6-11.

[6] Aziz, A., \& Dian, T., 2014. Implementasi Weighted Poduct dalam Penentuan Penerima Bantuan Langsung Masyarakat PNPM Mandiri Pedesaan, Prosiding Seminar Nasional Aplikasi Teknologi Informasi (SNATI), Yogyakarta.

[7] Effendy, 2014, Analisis Metode Simple Additive Weighting dan Weighted Product Untuk Decision Support System, Jurnal Inforrmatika, Vol. 5 (1), hal 27-39.

[8] Kusumadewi, S., 2006, Fuzzy MultiAttribute Decision Making, Graha Ilmu, Yogyakata. 